\title{
THE DPOBE MODEL FOR ORGANIZATIONAL SUSTAINABILITY: AN EXPLORATORY STUDY ABOUT ITS STRUCTURE, PILLARS AND COMPONENTS AMONG A GROUP OF MASTER DEGREE STUDENTS
}

\author{
Aníbal Areia, ${ }^{1}$ Francisco Esteves, ${ }^{2}$ João Rocha Santos, ${ }^{3}$ Pedro Anunciação ${ }^{4}$ \\ ${ }^{I}$ CICE-ESCE/IPS (Research Centre in Business Sciences) - Polytechnic Institute of Setúbal, Setúbal, Portugal, \\ anibal.areia@esce.ips.pt \\ ${ }^{2}$ CICE-ESCE/IPS (Research Centre in Business Sciences) - Polytechnic Institute of Setúbal, Setúbal, Portugal, \\ francisco.jm.esteves@esce.ips.pt \\ ${ }^{3}$ CICE-ESCE/IPS (Research Centre in Business Sciences) - Polytechnic Institute of Setúbal, Setúbal, Portugal, \\ joao.rocha.santos@esce.ips.pt \\ ${ }^{4}$ CICE-ESCE/IPS (Research Centre in Business Sciences) - Polytechnic Institute of Setúbal, Setúbal, Portugal, \\ pedro.anunciacao@esce.ips.pt
}

\begin{abstract}
Research purpose. To get a validation of the structure, pillars and components that seem to be central, and under which, business management and managers need to develop abilities and competences to ensure the sustainability of their organizations according to the 'DPOBE Model for Organizational Sustainability' structure.

Design/Methodology/Approach. For the validation of the structure, pillars and components and it's practical application to measure the organization's sustainability level with the referred model, despite the focus group exercise made in an early stage, it's also important to get a solid opinion about it among managers and also in academia, specifically among teachers and investigators on management, business administration and economics as well near master and doctorate students in this field. In this paper, we analyse the results obtained in an exploratory study, based on a survey made among students from four different master's degree in several specific areas of business management from the School of Business Administration from the Polytechnic Institute of Setúbal (Portugal).

Findings. Main results obtained with this exploratory study let the authors be granted with the developments made so far in the model and its structure, pillars and components. However, only with a major collection of opinions (answer to the survey) from the referred groups, it's possible to define and adjust the final structure and components of the DPOBE Model.

Originality/Value/Practical implications. Being an investigation with several years of development, with several articles, chapters of books, master's degree thesis, congress presentations and papers made so far, only with a solid and validated structure, pillars and components of the DPOBE Model for Organizational Sustainability, it's possible to go to its aim, the use of it as a quantitative tool to measure the effective organizations sustainability in a way different from other existing sustainability tools and indexes.
\end{abstract}

Keywords: Management; Organizational Sustainability; Competences; Sustainability Strength Index.

JEL codes: M19; L25.

\section{Introduction}

The importance of the subject 'sustainability' is becoming more and more relevant at the present time, making some justice to Elkington (2001) not only looking to an environmental perspective but also looking together to the social and economic influences on it.

The 'triple bottom line' approach proposed by Elkington (2001) remains so up-to-date that 'The Paris Agreement' (2019), established under the United Nations efforts, defined seventeen global objectives (C) 2020 Authors. This is an open-access article licensed under the Creative Commons Attribution-NonCommercial-NoDerivs License (http://creativecommons.org/licenses/by-nc-nd/3.0/) 
for a sustainable development to be achieve in 2030 regarding all this three sustainable dimensions.

The world is suffering from financial, economic and environmental situations and crisis, and recently, from pandemic global diseases, more often than any time before World War II and mainly in the recent past and nowadays.

All around the globe, this directly affected many companies, despite its economic, human and market dimensions, and exposed its incapacity to avoid or deal through this atypical situations.

Together with this insufficiency, sometimes managers take attitudes focused mainly on short-term earnings and profits without taking into account the need of establishing a long-term strategic line, even changing sometimes corporate and financial data only to show to third parties and stakeholders 'good figures'.

The aim of this exploratory study is to get some more information following previous studies (Santos et al., 2013; Santos, 2012; Santos et al., 2012; Gisbert López et al., 2011, 2010) in order to establish a quantitative model to measure, in real time, the effective organizations sustainability in a way different from other existing sustainability tools and indexes, supported in some pillars and components that this and other authors consider to be central and where managers need to develop capacities and abilities, in a demand to get 'good business management' and, consequently, organizational sustainability.

As DPOBE Model for Organizational Sustainability as its structure mainly settle, after several steps of investigation including the use of focus group methodology used in an early stage, seems also important to get an opinion about it among managers and also in academia, specifically among teachers and investigators on management, business administration and economics as well near master and doctorate students in this fields.

For this first exploratory study, a survey has been made among students from different master's degree courses in several specific areas of business management from the School of Business Administration of the Polytechnic Institute of Setúbal (Portugal).

The results obtained with this methodology, despite being a first approach with only almost seventy master's degree respondents, reveal a general approval from them of the structure, pillars and components settled on the DPOBE Model, despite some differences observed on the importance given to the five pillars and also in some groups of competences and dimensions from each pillar.

\section{Literature Review}

There are different approaches to the concept of corporate sustainability (Coral, 2002).

Table 1. Different perspectives on the concept of sustainability (Source: The Authors, 2020)

\begin{tabular}{|l|l|}
\hline Perspective & Authors \\
\hline Ecological vision & Epelbaum, 2004; Danich, 2003; Atkinson, 2000 \\
\hline $\begin{array}{l}\text { 'Eco-efficiency', 'Socio-effectiveness', 'Socio-efficiency', } \\
\text { 'Eco-effectiveness', 'Eco-equity' }\end{array}$ & $\begin{array}{l}\text { Dyllick \& Hockerts, 2002; Chen, Boudreau \& Watson, } \\
2008\end{array}$ \\
\hline Economic, physical and social stages & Anderson, 2006; Ehrenfeld, 2005; Dunphy, 2003 \\
\hline $\begin{array}{l}\text { Integration of economic, environmental, and social goals } \\
\text { (Triple bottom line - TBL) }\end{array}$ & Huemann \& Silvius, 2017 \\
\hline Relational perspective between stakeholders & $\begin{array}{l}\text { Moldavanova \& Goerdel, 2018; Oliveira, 2007; Almeida, } \\
\text { 2007; Donaire, 2006; Santoro, 2003; Elkington, 2001 }\end{array}$ \\
\hline A mission statement and strategy & Duan, 2019 \\
\hline System of determinants & Horak, Arya \& Ismail, 2018 \\
\hline Performance and business value & (Tworek; Walecka-Jankowska, \& Zgrzywa-Ziemak, 2019) \\
\hline
\end{tabular}


Although this approach may differ in the aspects or elements evidenced in each one, they end up complementing each other as shown in the table before, which evidences the richness of the concept and the diversity of the associated factors.

Some authors focus on the nature of the different dimensions of the concept of sustainability, such as an ecological vision (Epelbaum, 2004; Danich, 2003; Atkinson, 2000) or 'eco-efficiency', 'socioeffectiveness', 'socio-efficiency', 'eco-effectiveness' as important principles (Dyllick \& Hockerts, 2002).

Other authors reflected the different dimensions that sustainability must contemplate as a subject mainly sustained in economic, physical and social stages, regarding an environment supported in a systemic concept reinforced in ethical principles and social responsibility culture in businesses' development (Anderson, 2006; Ehrenfeld, 2005; Dunphy, 2003), or as an one based with the integration of economic, environmental, and social goals, known as the triple bottom line (TBL) (Huemann \& Silvius, 2017).

However, other authors consider that the importance of this economic, environmental and social TBL integration should make sense in the area of sustainability, through a new strategic view and an approach that fits a strong collaboration with different stakeholders and their interests, also taking into account the environmental impact of their activities (Oliveira, 2007; Almeida, 2007; Donaire, 2006; Santoro, 2003; Elkington, 2001).

Moldavanova \& Goerdel (2018) consider that this relational perspective should be sustained, among others, in internal organizational relationships, audience diversity and institutions established by organizations in order to enhance their social connections, such as public outreach departments.

In this line of thinking, authors such as Duan (2019) consider that sustainability should correspond to a clear mission statement and strategy in organizations. It should also consider several determinants such as Government intervention, regulations imposed by industry and legal stakeholders, societal expectations, relationship-oriented socialization, alliance between partners' culture and power status, organizational uncertainty and crisis, commercially based socialization, top management characteristics and exposure and corporate culture orientation (Horak, Arya \& Ismail, 2018), which should be evaluated through the analysis of dimensions such as organizational performance, information systems' capabilities, business value and information technologies' value (Tworek, Walecka-Jankowska \& Zgrzywa-Ziemak, 2019).

While there are several approaches in an attempt to address the best model or approach to sustainability, Svirina (2009) warns that the efficiency of organizations, many times, is not an outcome of an efficient management, showing 'good numbers' about social, economic and environmental issues in corporate reports is not enough to reveal an organization as really sustainable.

Svirina (2009) also referred that there is no direct relation between profits and a good companies' management and shareholders' value, as well as corporations' efficiency can't be measured by its annual profits.

Following this idea, a 'good' organizations' short-term performance, mainly calculated with annual balance sheet information and accounting figures, may 'cover' difficulties to get a medium and long term sustainability (Baumgartner \& Ebner, 2010).

According to this, Santos (2012) referred that the information exposed by several organizations about its environmental, social and financial data are not 'transparent' according to real results, being the same many times manipulated according to the interests of individuals, groups and corporations about the impact of their activities in different contexts.

As Stacey (1993) referred since some time ago, the challenge of sustainability remains in the balance among differentiated and difference maker's abilities of the performance of organizations, conditioning and starting all these on three main axes: 'Discontinuance' versus 'Continuance'; 'Integration' versus 'Differentiation'; 'Complexity' versus 'Instability'.

It's based on these facts that, in recent past, the authors tried to develop, improve and validate a model that provides a holistic and pragmatic approach to organizational sustainability. 
Several articles, chapters of books, master's degree thesis, congress presentations and papers have been written by these authors since 2010, regarding applications of the original empirical model and other developments made so far (Santos et al., 2013; Santos, 2012; Santos et al., 2012; Gisbert López, et al., 2011, 2010)

This context of insufficiency and lack of consistent information let some authors (Gisbert López et al., $2011,2010)$ to develop a theoretical model aiming to disclose the main features that seem crucial to get organizations' sustainability, the 'DPOBE Model for Organizational Sustainability'.

This model is supported in the five pillars that an organizations' managers should grow their capabilities and skills.

- 'Direction', related with organizations' economic 'sense', the way they 'view' the future and the development of the best way to achieve it (Santos, 2012; Gisbert López et al., 2010);

- 'Posture', concerning good management and ethical values, organizational credibility, working consistency, 'good attitudes and behaviours', 'confidence and new ideas' (Markides, 2000, 1997);

- 'Organization', related with management activities' measure, 'multi-dimensional and multicontextual' organization activities, alignment strategies and organizational dimensions, responsibilities and performances (Kim \& Mauborgne, 2003);

- 'Behaviour', 'forcing' quality organizations, quality measure, quality standards, efficiency and effectiveness (Andrade \& Anunciação, 2009, 2008; Anunciação \& Zorrinho, 2006; Yang et al., 2005; Grupe et al., 2002; Zeithaml, 2002, 2001; Yoo \& Donthu, 2001);

- 'Evaluation', related with organizational performance, strategic objectives and options, performance and risk, capacities and resources for critical opportunities and to solve problems (Wolfinbarger \& Gilly, 2002; Rajkumar \& Mani, 2001; Rodrigues, 2000).

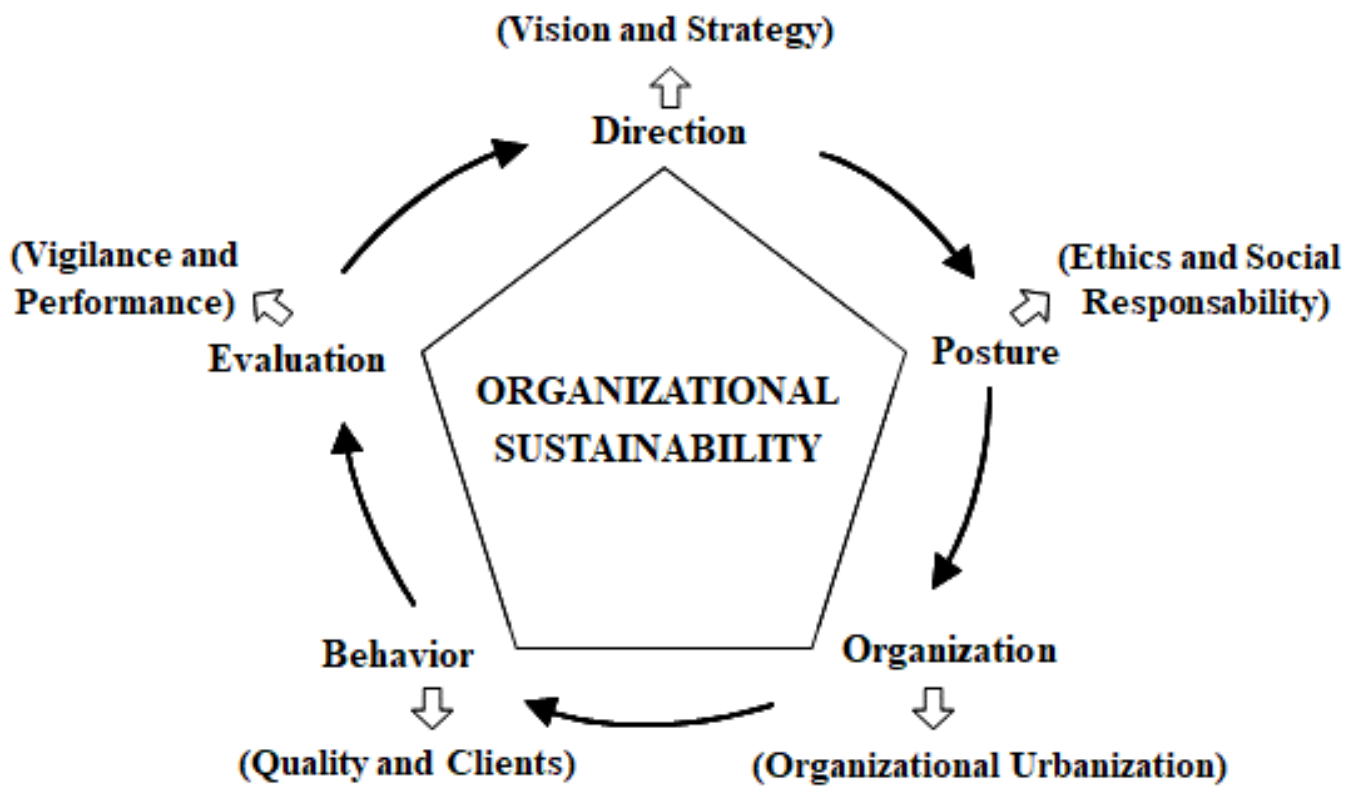

Fig. 1. The DPOBE Model for Organizational Sustainability (Source: G. López et al., 2011, 2010)

Some empirical studies were conducted that applied to two big Portuguese companies (Santos, 2012; Gisbert López et al., 2010). 
Meanwhile, some of the authors proposed an upgrade of the initial model to a quantitative application able to measure the global sustainability robustness of organizations, supported in the sustainability strength in each of the five pillars (Santos et al., 2012).

In order to achieve this aim, a group of competences and dimensions was set in each of the pillars to be analysed according to their objectivity and scope of information in four different levels of organizations.

The authors used 'focus group' technique with a group of academic researchers in the field of management together with management professionals. It is a powerful research tool and methodological approach that provided, in this case, some perceptions and a suitable assortment, mixture and set of points of view, as Boateng (2012) and Bishop (2006) referred when defending this research technique.

Following this line of investigation, some of the authors tried to make an upgrade of the sustainability model, defining previously a set of items and conditions to transform it in a quantitative method to determine the global sustainability robustness of organizations (Santos et al., 2013).

The levels in organizations that were chosen to be analysed are:

- 'Strategic level';

- 'Operational level', related with organizational and functional planning as well as short and long term planning;

- 'Top management level', regarding administration written records and resolutions;

- 'Activity reports', regarding official accounting, revision and management reports as well as sustainability reports.

Two dimensions to be evaluated were defined in each previous level:

- 'Objectivity', regarding the way each parameter and competence is formally declared and defined;

- 'Scope and Knowledge', related with the disclosure within organizations of each competence and parameter.

They established, in each one of the five pillars of the organizations (Direction, Posture, Organization, Behaviour and Evaluation), nine (9) parameters and competences to be examined in each one (Santos et al., 2013).

They defined a Likert scale with six (6) different values in order to rate each one of the parameters and competences to be examined in each one of the five pillars of the organizations (from 5 - 'Explicitly defined and well exposed and applied' to 0 - 'Don't know/don't answer/not applicable').

The average of the acquired results in each one of the parameters and competences makes possible the definition of the 'sustainability strength of each pillar' (in a scale from 0 to 5).

With the sum/average of all 'sustainability strength of each pillar' we get the 'sustainability robustness of the global organization', in a scale between 'Extremely robust' (equal or more than 5 or 22 points) and 'Without robustness' (less than 1 or 4 points).

According to what was mentioned earlier, is established an 'Organizational Sustainable Robustness Index $\left(\mathrm{R}_{\mathrm{S}}\right)$ ', supported in the sustainable strength indexes of each pillar of the model:

$$
\mathrm{R}_{\mathrm{S}}=\mathrm{f}(\mathrm{Si})
$$

where

$\mathrm{S}_{\mathrm{i}}$ : Sustainable Strength Index of each pillar of the DPOBE Model

$\mathrm{R}_{\mathrm{S}}$ : Organizational Sustainable Robustness Index 


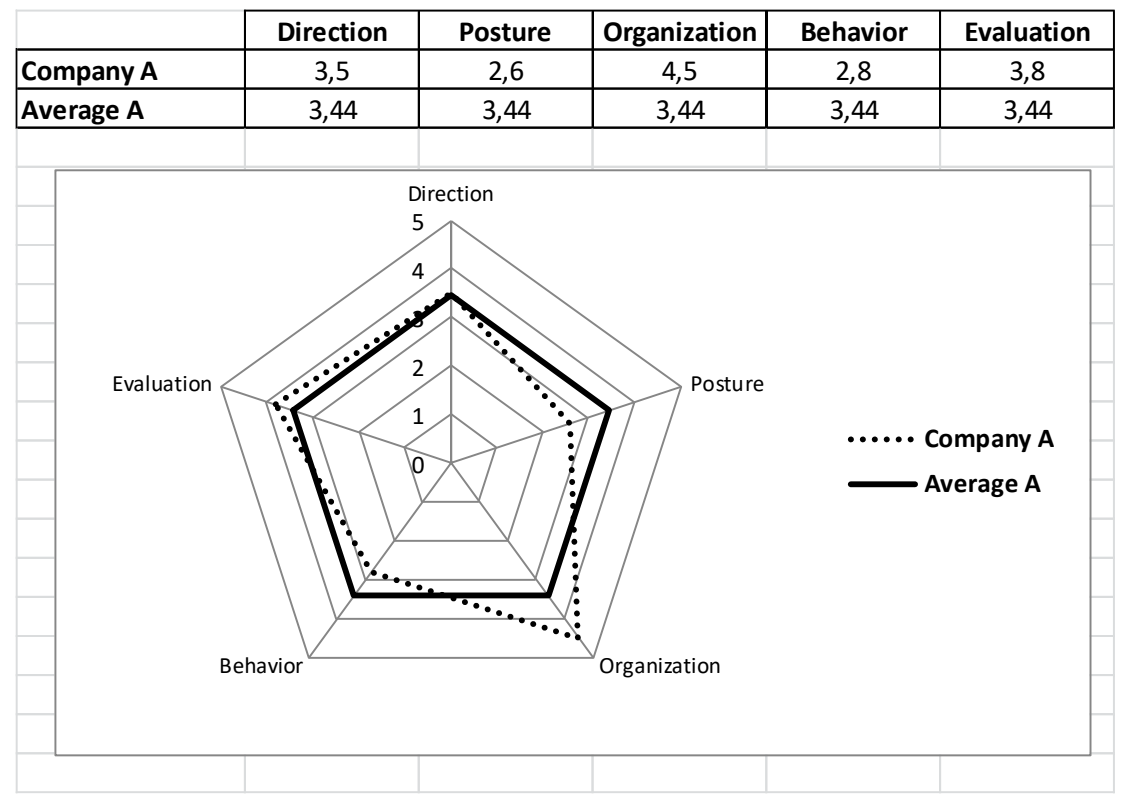

Fig. 2. Example of a Company Sustainable Strength Indexes (Source: Santos et al., 2013)

With this type of sustainable index, it is possible to compare, for example, the sustainability strength in each pillar and the global sustainability robustness index of an organization with a set of companies in the same business sector.

\begin{tabular}{|l|c|c|c|c|c|c|}
\cline { 2 - 7 } \multicolumn{1}{c|}{} & Direction & Posture & Organization & Behavior & Evaluation & Robustness \\
\hline Company A & 3,5 & 2,6 & 4,5 & 2,8 & 3,8 & 17,2 \\
\hline Company B & 3,5 & 1,6 & 2,5 & 3,8 & 4,1 & 15,5 \\
\hline Company C & 4,1 & 0,6 & 3,5 & 1,9 & 4,8 & 14,9 \\
\hline Company D & 2,5 & 2,6 & 3,7 & 2,4 & 3,2 & 14,4 \\
\hline Company E & 1,8 & 2,6 & 2,2 & 3,1 & 3,6 & 13,3 \\
\hline
\end{tabular}

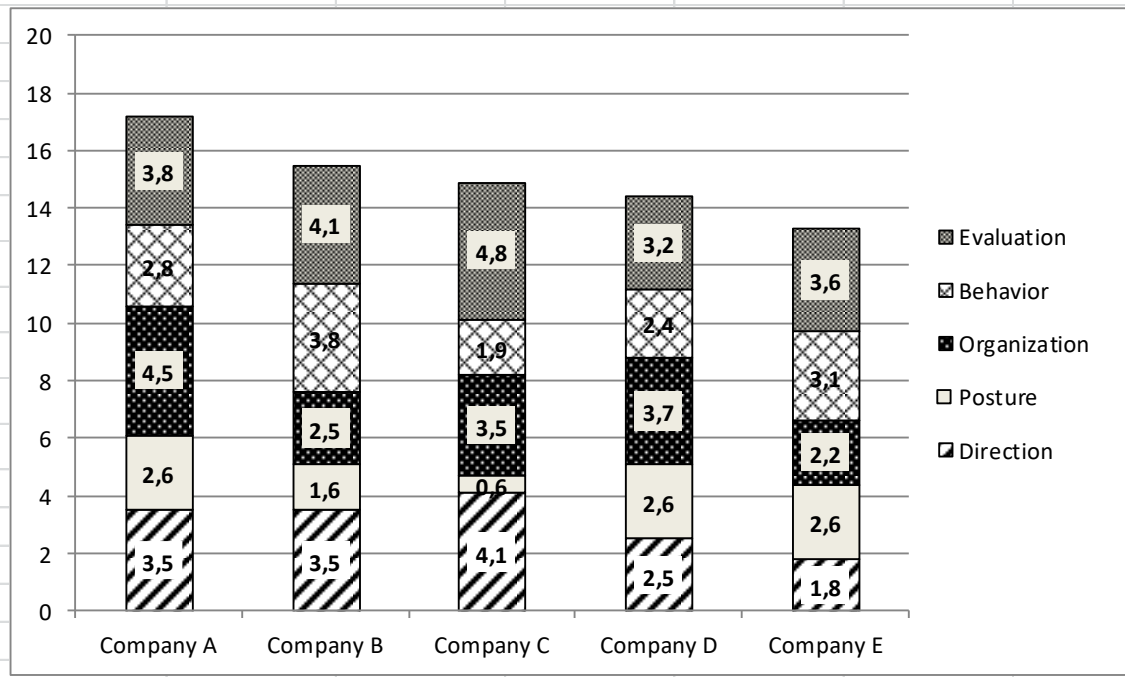

Fig. 3. Example of a Group of Companies Sustainability Strengths/Robustness (Source: Santos et al., 2013) 
The sustainable robustness index of a set of reference companies from the same business sector can be also formalized as a mathematical function, giving the possibility to reveal, for example, a pattern of sustainability of a business sector and put in evidence a set of factors that can be representative of a similar management behaviour, skills and other key-conditions.

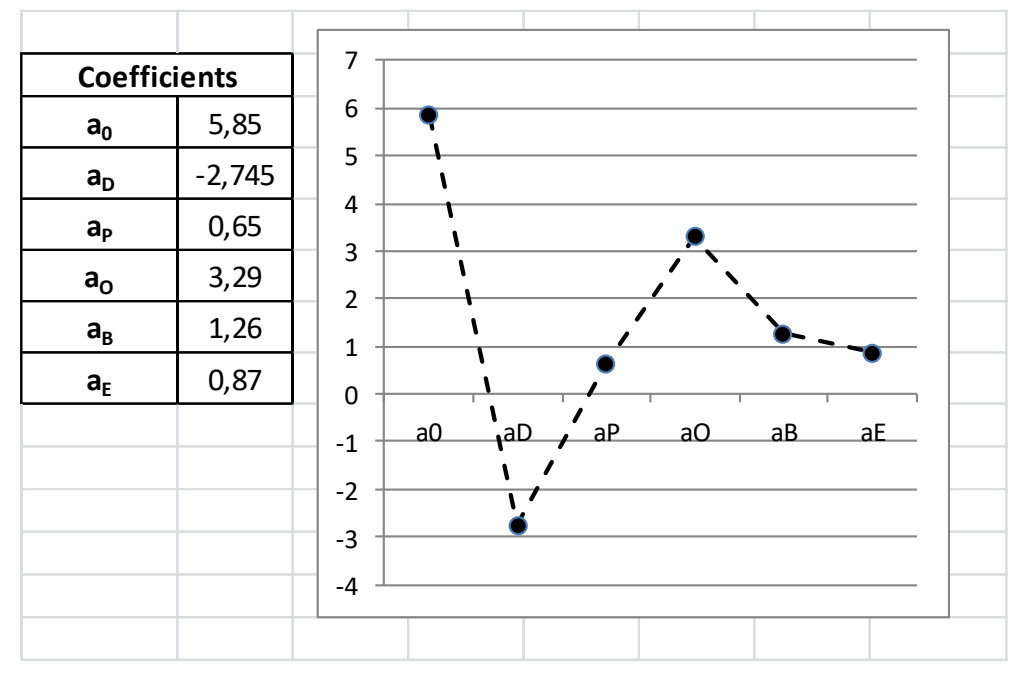

Fig. 4. Example of a Group of Companies Statistical Inference (Source: Santos et al., 2013)

$$
R_{S}=R_{0}+a_{D} \cdot S_{D}+a_{P} \cdot S_{P}+a_{O} \cdot S_{O}+a_{B} \cdot S_{B}+a_{E} \cdot S_{E}
$$

where

\author{
$\mathrm{R}_{0}$ : Independent coefficient; \\ $S$ \\ D,P,O,B,E: Sustainable Strength Indexes of each pillar of the DPOBE Model \\ $a_{D, P, O, B, E}:$ Coefficients of each Sustainable Strength Indexes
}

\begin{abstract}
Methodology
To the authors and others related with the origin of this sustainability model, it's crucial to conduct the validation of its structure, pillars and components and the practicability of its application in order for it to be a tool to measure the organization's sustainability.

Despite the focus group exercise conducted in an early stage, it's also important to get a solid opinion about it among managers and also in academia, specifically among teachers and investigators in the fields of management, business administration and economics as well near master and doctorate students in this fields.

In this paper, we analysed the results obtained in an exploratory study, based on a survey made among students from several master's degree courses in several specific areas of business management from the School of Business Administration from the Polytechnic Institute of Setúbal (Portugal).

The choice of master's students was due to the fact that they are management staff in its majority, and because they are consolidating knowledge and want to improve their skills in several areas of management.
\end{abstract}

These characteristics allowed them to be a relevant sample for this exploratory study. Sustainability is a theme of great relevance in the current context of the economy as others before, mainly due to the 
pandemic Covid 19 that led to the closure of many small and medium businesses and the layout of others.

The survey mainly asked about the level of importance given by the respondents in each one of the pillars, in the settled parameters and competences of each one and the objectivity, scope and knowledge of each pillar in the chosen four levels in organizations.

The group of master's degree students asked to answer to this exploratory survey was composed of a total of 95 students, distributed in four different master's degree courses in several specific areas of business management (Business Sciences, Accounting and Finance, Information Systems Management and Strategic Human Resources Management).

The level of valid answers to the survey was almost $70 \%$ of the inquired group (66 students), making no sense in this exploratory study of the application of any methodologies to validate the sample of valid answers considering the small number of persons in the universe explored.

Valid answers were classified in their main characteristics, as follows.
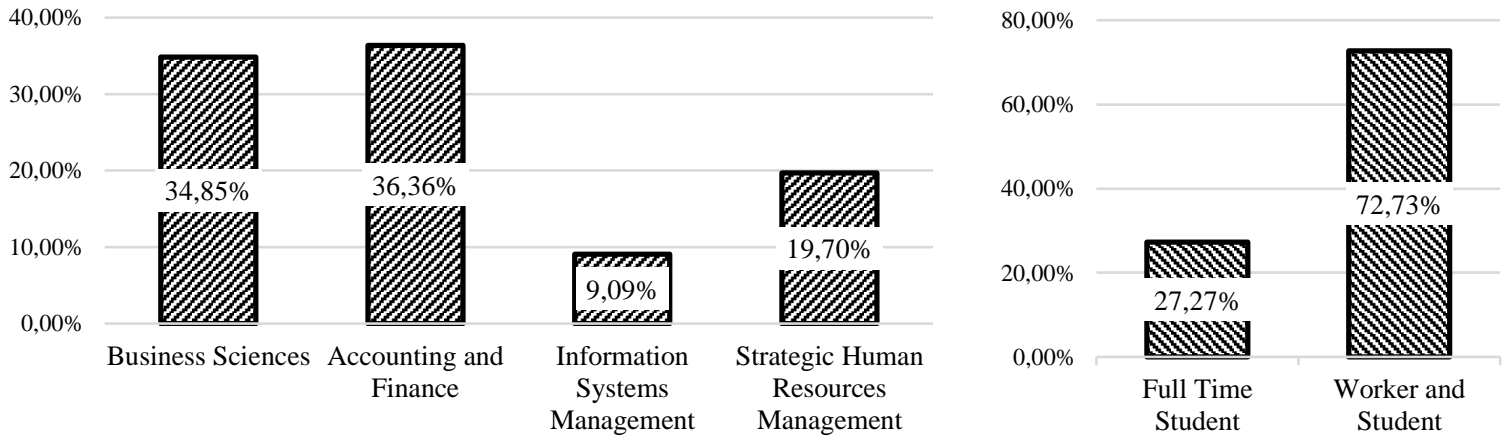

Fig. 5. Distribution by Master Degree Courses and Type of Student (Source: The Authors, 2020)

Almost $90 \%$ of the inquired group have working experience outside school, with more than $60 \%$ of them with more than 5 years of working experience.

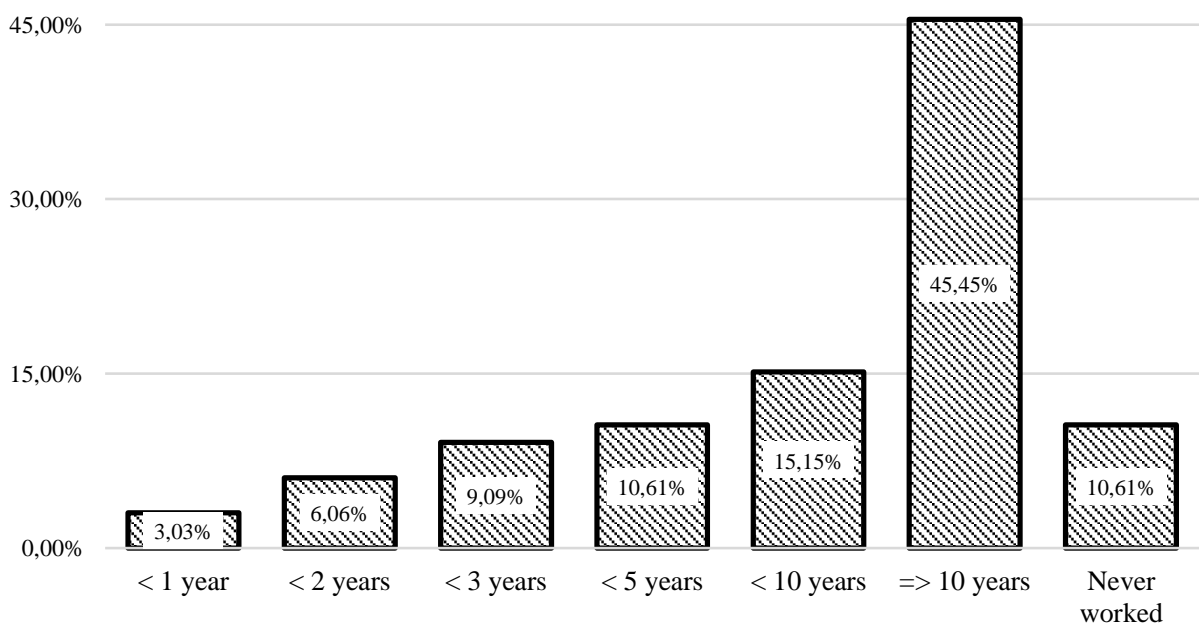

Fig. 6. Distribution by Working Experience (Source: The Authors, 2020) 
Also almost $41 \%$ of the respondent students have actually top level or first line working positions in the organizations they work, being the 'Administrative Technician' the working position with more frequency, almost $40 \%$ of the inquired group.

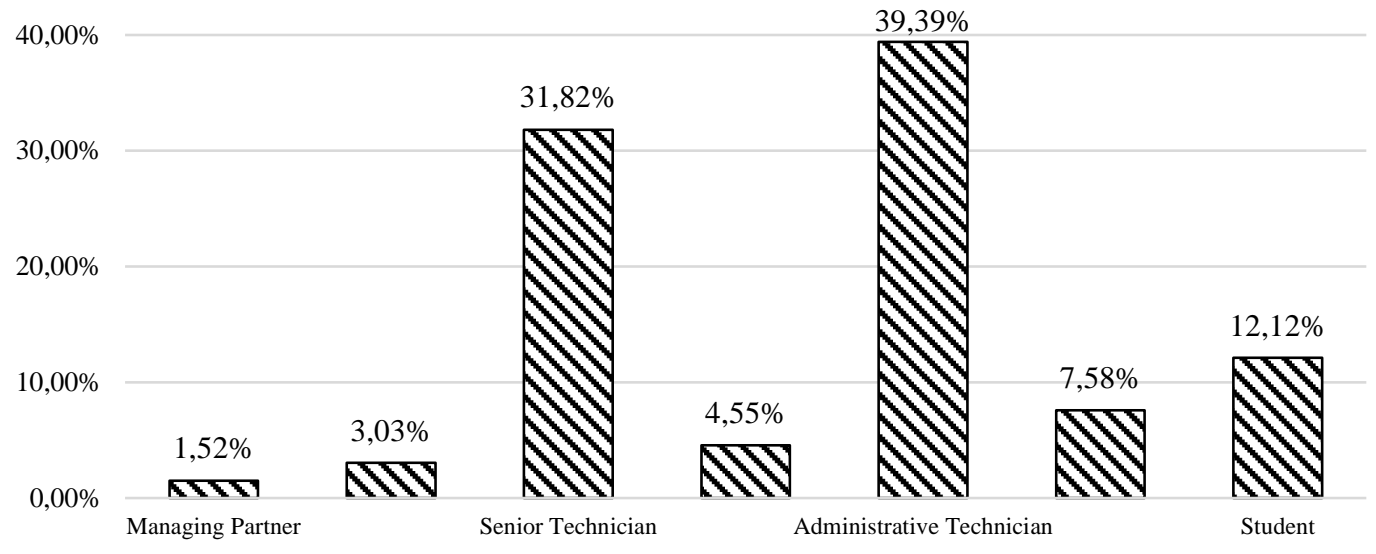

Fig. 7. Distribution by Working Position (Source: The Authors, 2020)

Regarding the perception of the present working respondent students on the organizations they work about its concerns and effective actions about sustainability issues, they are the following, with a special remark in the lack of information of the working respondents on social and economic sustainability issues and the lower level of knowledge about environmental concerns and effective actions.

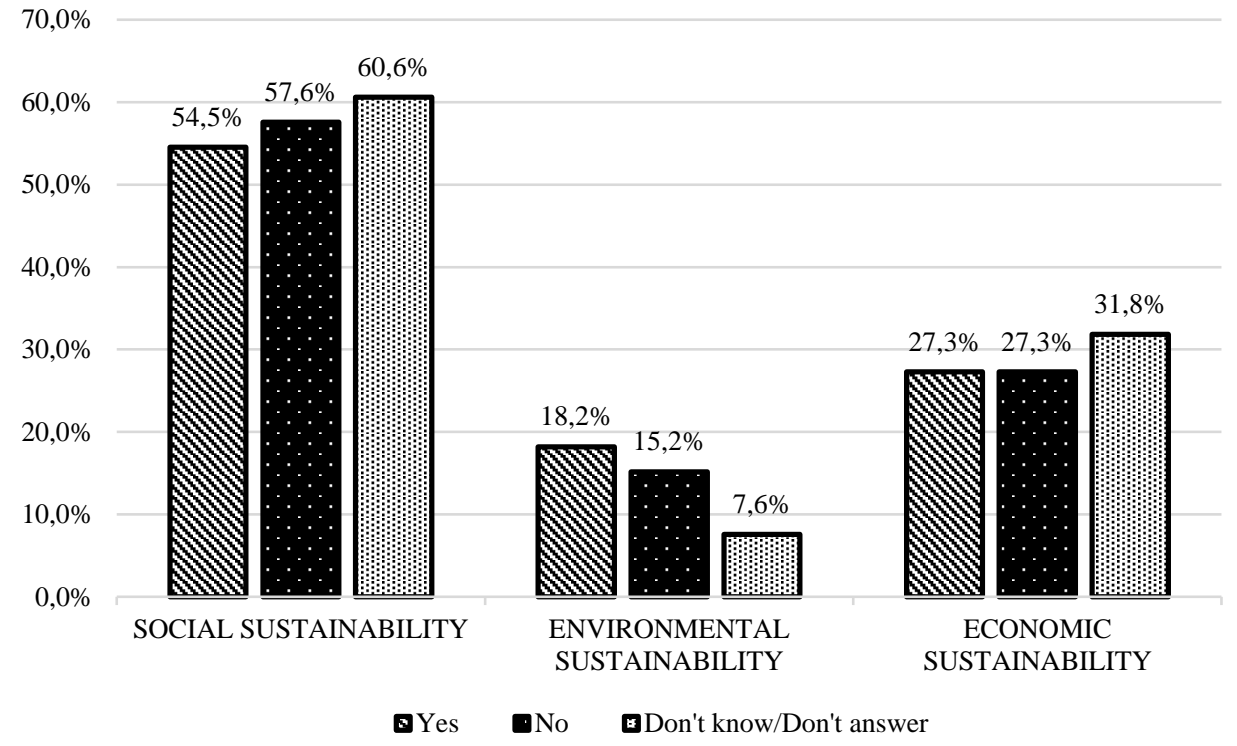

Fig. 8. Perception about Concerns and Actions on Sustainability Issues (Source: The Authors, 2020)

The knowledge of the inquired group about existing certified management systems in their own working companies revealed some lack of knowledge and a possible low information to them in their jobs, putting in question the way their companies work and the required positioning and action of each one in the possible existing certified systems and sub-systems. 


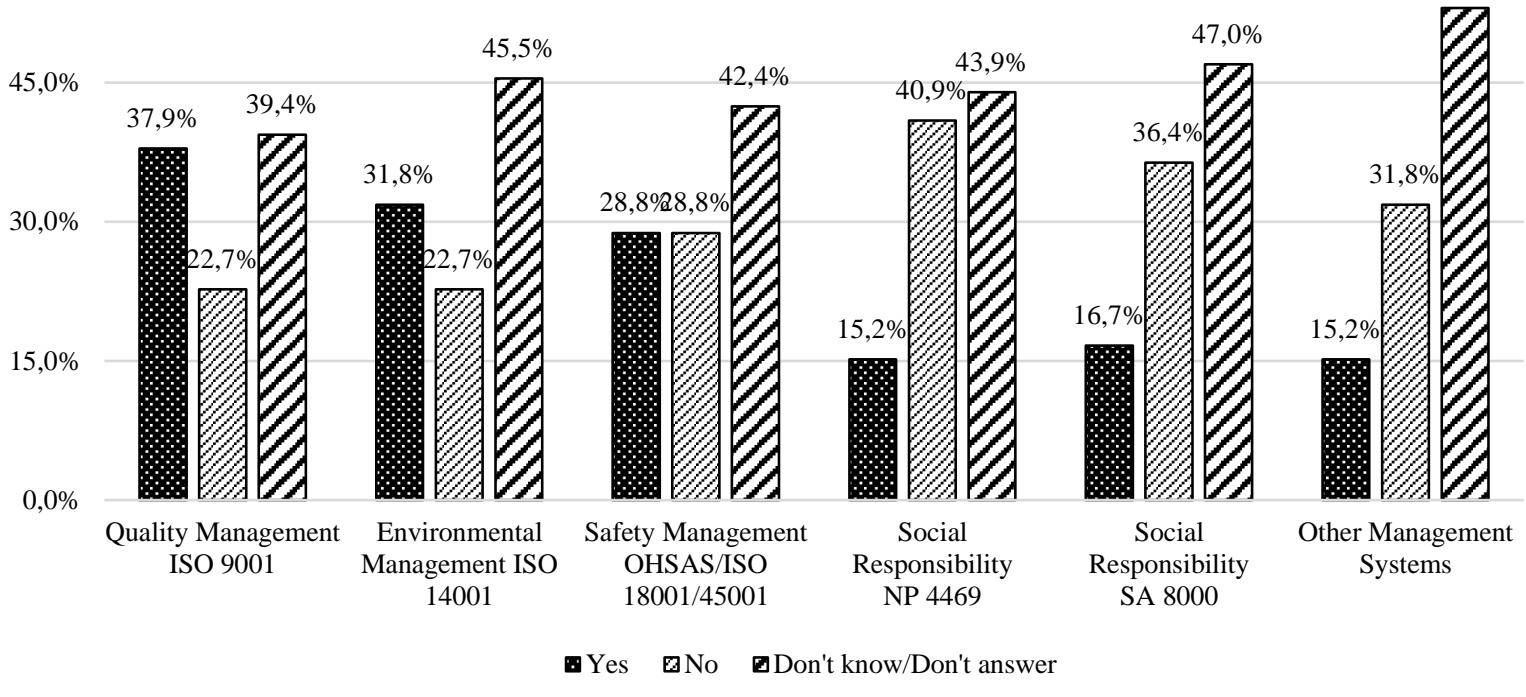

Fig. 9. Knowledge about Existing Certified Management Systems (Source: The Authors, 2020)

\section{Results}

Main results obtained in this exploratory study let the authors joyful with the developments made so far in the model and its structure, pillars and components.

The importance given by the respondent students in each one of the pillars as 'Very important' and 'Fundamental' reaches together approximately $85 \%$ or more of the total answers given, and this figure added with the answers of the respondent students as 'Important' raise up to approximately $97 \%$ of the total answers.

Table 2. Importance Given in Each Area/Pillar by the Respondents (Source: The Authors, 2020)

\begin{tabular}{|l|l|l|l|l|l|l|}
\cline { 2 - 7 } \multicolumn{1}{c|}{ Area/Pillar } & Insignificant & $\begin{array}{l}\text { Low } \\
\text { importance }\end{array}$ & Important & $\begin{array}{l}\text { Very } \\
\text { important }\end{array}$ & Fundamental & $\begin{array}{l}\text { Don't } \\
\text { know/don't } \\
\text { answer }\end{array}$ \\
\hline DIRECTION & $0.00 \%$ & $0.00 \%$ & $10.61 \%$ & $36.36 \%$ & $50.00 \%$ & $3.03 \%$ \\
\hline POSTURE & $0.00 \%$ & $1.52 \%$ & $9.09 \%$ & $34.85 \%$ & $54.55 \%$ & $0.00 \%$ \\
\hline ORGANIZATION & $0.00 \%$ & $0.00 \%$ & $12.12 \%$ & $33.33 \%$ & $54.55 \%$ & $0.00 \%$ \\
\hline BEHAVIOUR & $0.00 \%$ & $0.00 \%$ & $9.09 \%$ & $37.88 \%$ & $50.00 \%$ & $3.03 \%$ \\
\hline EVALUATION & $0.00 \%$ & $0.00 \%$ & $13.64 \%$ & $37.88 \%$ & $46.97 \%$ & $1.52 \%$ \\
\hline
\end{tabular}

On the other hand almost nobody considered 'Insignificant' or with 'Low importance' any of the considered pillars, as well as only a few respondents declared 'Don't know/don't answer' about some of the pillars. 
Table 3. Importance of the Parameters/Competences in Each Pillar (Source: The Authors, 2020)

\begin{tabular}{|c|c|c|c|c|c|c|}
\hline $\begin{array}{l}\text { Parameters/Competences } \\
\text { Pillar 'DIRECTION' }\end{array}$ & Insignificant & $\begin{array}{l}\text { Low } \\
\text { importance }\end{array}$ & Important & $\begin{array}{l}\text { Very } \\
\text { important }\end{array}$ & Fundamental & $\begin{array}{l}\text { Don't } \\
\text { know/don't } \\
\text { answer }\end{array}$ \\
\hline Mission, Values and Organization Policies & $0.0 \%$ & $0.0 \%$ & $13.6 \%$ & $31.8 \%$ & $53.0 \%$ & $1.5 \%$ \\
\hline $\begin{array}{l}\text { Business Strategy and Definition of Strategic } \\
\text { Objectives }\end{array}$ & $0.0 \%$ & $0.0 \%$ & $6.1 \%$ & $34.8 \%$ & $57.6 \%$ & $1.5 \%$ \\
\hline $\begin{array}{l}\text { Time Frame and Quantification of Strategic } \\
\text { Objectives }\end{array}$ & $0.0 \%$ & $0.0 \%$ & $18.2 \%$ & $39.4 \%$ & $39.4 \%$ & $3.0 \%$ \\
\hline $\begin{array}{l}\text { Integration of Business Strategy in the Economic } \\
\text { Group Policy and Strategy (if applicable) }\end{array}$ & $0.0 \%$ & $0.0 \%$ & $18.2 \%$ & $42.4 \%$ & $34.8 \%$ & $4.5 \%$ \\
\hline Action Markets ('Where?') & $0.0 \%$ & $0.0 \%$ & $22.7 \%$ & $36.4 \%$ & $36.4 \%$ & $4.5 \%$ \\
\hline Target Customers ('Who?') & $0.0 \%$ & $1.5 \%$ & $19.7 \%$ & $28.8 \%$ & $47.0 \%$ & $3.0 \%$ \\
\hline Products and Services ('What?') & $0.0 \%$ & $0.0 \%$ & $22.7 \%$ & $37.9 \%$ & $36.4 \%$ & $3.0 \%$ \\
\hline Time-to-Market ('When?') & $0.0 \%$ & $0.0 \%$ & $22.7 \%$ & $43.9 \%$ & $28.8 \%$ & $4.5 \%$ \\
\hline Product and Services Placement ('How?') & $0.0 \%$ & $0.0 \%$ & $19.7 \%$ & $39.4 \%$ & $34.8 \%$ & $6.1 \%$ \\
\hline
\end{tabular}

\begin{tabular}{|l|l|l|l|l|l|}
\hline $\begin{array}{l}\text { Parameters/Competences } \\
\text { Pillar 'POSTURE' }\end{array}$ & Insignificant & $\begin{array}{l}\text { Low } \\
\text { importance }\end{array}$ & Important & $\begin{array}{l}\text { Very } \\
\text { important }\end{array}$ & $\begin{array}{l}\text { Fundamental } \\
\text { know/don't } \\
\text { answer }\end{array}$ \\
\hline Corporate Culture and Values & $0.0 \%$ & $0.0 \%$ & $18.2 \%$ & $39.4 \%$ & $42.4 \%$ \\
\hline Ethical Principles & $0.0 \%$ & $1.5 \%$ & $12.1 \%$ & $27.3 \%$ & $57.6 \%$ \\
\hline Organizational Principles and Code of Conduct & $0.0 \%$ & $0.0 \%$ & $12.1 \%$ & $36.4 \%$ & $50.0 \%$ \\
\hline $\begin{array}{l}\text { Social Responsibility Principles and Code of } \\
\text { Conduct }\end{array}$ & $0.0 \%$ & $0.0 \%$ & $15.2 \%$ & $40.9 \%$ & $42.4 \%$ \\
\hline Environmental Principles and Code of Conduct & $0.0 \%$ & $3.0 \%$ & $15.2 \%$ & $37.9 \%$ & $42.4 \%$ \\
\hline Professional Principles and Codes of Conduct & $0.0 \%$ & $0.0 \%$ & $12.1 \%$ & $39.4 \%$ & $47.0 \%$ \\
\hline $\begin{array}{l}\text { Principles of Relationship with Suppliers } \\
\text { Principles of Action and Participation in the } \\
\text { Community }\end{array}$ & $0.0 \%$ & $3.0 \%$ & $18.2 \%$ & $45.5 \%$ & $30.3 \%$ \\
\hline Legal Framework of Organizational Activities & $0.0 \%$ & $0.0 \%$ & $13.6 \%$ & $31.8 \%$ & $53.0 \%$ \\
\hline
\end{tabular}

\begin{tabular}{|c|c|c|c|c|c|c|}
\hline $\begin{array}{l}\text { Parameters/Competences } \\
\text { Pillar 'ORGANIZATION' }\end{array}$ & Insignificant & $\begin{array}{l}\text { Low } \\
\text { importance }\end{array}$ & Important & $\begin{array}{l}\text { Very } \\
\text { important }\end{array}$ & Fundamental & $\begin{array}{l}\text { Don't } \\
\text { know/don't } \\
\text { answer }\end{array}$ \\
\hline Organizational Structure & $0.0 \%$ & $1.5 \%$ & $13.6 \%$ & $40.9 \%$ & $42.4 \%$ & $1.5 \%$ \\
\hline $\begin{array}{l}\text { Compatibility and Integration of the } \\
\text { Organizational Structure in the Economic Group } \\
\text { (if applicable) }\end{array}$ & $0.0 \%$ & $0.0 \%$ & $19.7 \%$ & $47.0 \%$ & $31.8 \%$ & $1.5 \%$ \\
\hline $\begin{array}{l}\text { Organization Functional Charts and Operating } \\
\text { Standards }\end{array}$ & $0.0 \%$ & $0.0 \%$ & $27.3 \%$ & $34.8 \%$ & $36.4 \%$ & $1.5 \%$ \\
\hline $\begin{array}{l}\text { Organizational Information and Communication } \\
\text { Systems }\end{array}$ & $0.0 \%$ & $1.5 \%$ & $13.6 \%$ & $36.4 \%$ & $47.0 \%$ & $1.5 \%$ \\
\hline $\begin{array}{l}\text { Training and Information to Employees, } \\
\text { Suppliers and Subcontractors }\end{array}$ & $0.0 \%$ & $0.0 \%$ & $18.2 \%$ & $42.4 \%$ & $37.9 \%$ & $1.5 \%$ \\
\hline Planning of Activities and Resources Distribution & $0.0 \%$ & $0.0 \%$ & $27.3 \%$ & $36.4 \%$ & $34.8 \%$ & $1.5 \%$ \\
\hline Strategic Business Partnerships & $0.0 \%$ & $1.5 \%$ & $24.2 \%$ & $53.0 \%$ & $19.7 \%$ & $1.5 \%$ \\
\hline $\begin{array}{l}\text { Business Units, Geographic Business Areas and } \\
\text { Branches/Delegations }\end{array}$ & $0.0 \%$ & $0.0 \%$ & $30.3 \%$ & $42.4 \%$ & $22.7 \%$ & $4.5 \%$ \\
\hline Organizational Structure & $0.0 \%$ & $1.5 \%$ & $13.6 \%$ & $40.9 \%$ & $42.4 \%$ & $1.5 \%$ \\
\hline
\end{tabular}


Table 3. (Continuing) Importance of the Parameters/Competences in Each Pillar (Source: The Authors, 2020)

\begin{tabular}{|l|l|l|l|l|l|}
\hline $\begin{array}{l}\text { Parameters/Competences } \\
\text { Pillar 'BEHAVIOUR' }\end{array}$ & Insignificant & $\begin{array}{l}\text { Low } \\
\text { importance }\end{array}$ & Important & $\begin{array}{l}\text { Very } \\
\text { important }\end{array}$ & $\begin{array}{l}\text { Fundamental } \\
\text { know/don't } \\
\text { answer }\end{array}$ \\
\hline Certifications and Management Sub-systems & $0.0 \%$ & $1.5 \%$ & $28.8 \%$ & $39.4 \%$ & $27.3 \%$ \\
\hline Effectiveness Level (Achievement of Objectives) & $0.0 \%$ & $0.0 \%$ & $22.7 \%$ & $36.4 \%$ & $37.9 \%$ \\
\hline Efficiency Level (Use of Resources) & $0.0 \%$ & $0.0 \%$ & $15.2 \%$ & $34.8 \%$ & $47.0 \%$ \\
\hline Productivity Levels & $0.0 \%$ & $0.0 \%$ & $19.7 \%$ & $42.4 \%$ & $34.8 \%$ \\
\hline Internal Audits & $0.0 \%$ & $4.5 \%$ & $22.7 \%$ & $40.9 \%$ & $28.8 \%$ \\
\hline Customers and Employees Satisfaction Analysis & $0.0 \%$ & $1.5 \%$ & $13.6 \%$ & $28.8 \%$ & $53.0 \%$ \\
\hline Actions on Internal Failures and Complaints & $0.0 \%$ & $1.5 \%$ & $16.7 \%$ & $37.9 \%$ & $40.9 \%$ \\
\hline Improvement Processes & $0.0 \%$ & $0.0 \%$ & $10.6 \%$ & $36.4 \%$ & $50.0 \%$ \\
\hline $\begin{array}{l}\text { Compatibility between Strategy and Operational } \\
\text { Actions }\end{array}$ & $0.0 \%$ & $1.5 \%$ & $21.2 \%$ & $39.4 \%$ & $34.8 \%$ \\
\hline
\end{tabular}

\begin{tabular}{|l|l|l|l|l|l|}
\hline $\begin{array}{l}\text { Parameters/Competences } \\
\text { Pillar 'EVALUATION' }\end{array}$ & Insignificant & $\begin{array}{l}\text { Low } \\
\text { importance }\end{array}$ & Important & $\begin{array}{l}\text { Very } \\
\text { important }\end{array}$ & $\begin{array}{l}\text { Fundamental } \\
\text { know/don't } \\
\text { answer }\end{array}$ \\
\hline Indicators and Evaluation Metrics & $0.0 \%$ & $0.0 \%$ & $21.2 \%$ & $36.4 \%$ & $39.4 \%$ \\
\hline Evaluation of Business Incomes & $0.0 \%$ & $0.0 \%$ & $12.1 \%$ & $37.9 \%$ & $47.0 \%$ \\
\hline $\begin{array}{l}\text { Comparison between Expected and Obtained } \\
\text { Results }\end{array}$ & $0.0 \%$ & $0.0 \%$ & $12.1 \%$ & $37.9 \%$ & $47.0 \%$ \\
\hline $\begin{array}{l}\text { Organizational Efficiency Monitoring } \\
\text { Organizational Effectiveness Monitoring }\end{array}$ & $0.0 \%$ & $0.0 \%$ & $16.7 \%$ & $39.4 \%$ & $40.9 \%$ \\
\hline $\begin{array}{l}\text { Economic and Market Analysis } \\
\text { Results }\end{array}$ & $0.0 \%$ & $0.0 \%$ & $16.7 \%$ & $37.9 \%$ & $42.4 \%$ \\
\hline $\begin{array}{l}\text { Forecast and Development of Future Scenarios } \\
\text { and Potential Markets }\end{array}$ & $0.0 \%$ & $1.5 \%$ & $18.2 \%$ & $43.9 \%$ & $33.0 \%$ \\
\hline \begin{tabular}{l} 
Strategic Realignment Procedures \\
\hline
\end{tabular} & $0.0 \%$ & $0.0 \%$ & $22.7 \%$ & $37.9 \%$ & $36.4 \%$ \\
\hline
\end{tabular}

It's verified that the majority of respondents considered 'Very important' or 'Fundamental' as the importance they gave to the majority of parameters and competences of all pillars.

The importance given, in each of the pillars, by the respondent students in the parameters/competences was between $91 \%$ and $100 \%$, if adding together the number of classifications 'Important', 'Very important' and 'Fundamental', with the last two achieving combined values between $65.2 \%$ and $92.4 \%$.

The only exclusion is in the parameter/competence 'Outsourcing of Activities, Functions and Tasks' in the pillar 'Organization' with only $48.5 \%$ in both classifications 'Very important' and 'Fundamental'.

None of the respondents considered 'Insignificant' in all parameters and only a very few considered 'Low importance' in some parameters, and some few respondents answered 'Don't know/don't answer' as well.

Similar results were obtained in this survey about the importance given to the four levels in organizations chosen to be analysed in each one of the five pillars, each one according to the two dimensions defined to be evaluated, the 'Objectivity' and the 'Scope and Knowledge'.

The importance given by the majority of questioned students to the four levels in organizations chosen to be analysed in each pillar was between $91 \%$ and more than $98 \%$, regarding the combined number of classifications 'Important', 'Very important' and 'Fundamental', with the last two achieving combined values between $57.6 \%$ and $77.3 \%$. 
None of the respondents considered 'Insignificant' in the four levels for each pillar. In the pillar 'Evaluation', it was found that at two levels, some respondents (1.5\%) considered it 'Insignificant'.

At some levels of valuation and in all pillars, very few respondents considered it as 'Low importance' and only a very few have stated that 'Don't know/don't answer'.

\section{Conclusions}

The results obtained with this small exploratory study somehow revealed the importance of the main subject studied some years ago and the validity and importance of the goals it sought to achieve, that is, an improvement of the original theoretical model in order to develop a quantitative tool to measure the sustainability of organizations.

One practical value achieved with this brief exploratory study was getting a small insight about the perception of second cycle students regarding the sustainability of organizations and businesses, especially from the ones that already have work experience outside school.

This small exploratory survey also drew the authors' attention to some answers regarding the expressed ignorance in some competences/parameters as they considered that 'Don't know/don 't answer', together with the classification given by some of the inquired students in some competences/parameters of the pillar 'Evaluation' as 'Insignificant'.

However, only with a major collection of opinions (answers to survey) from this specific group (master and doctorate students in the fields of management, business administration and economics, in Portugal and abroad), together with others (businesses and companies' managers and also teachers and investigators in the same fields of knowledge), it was possible to define and adjust the final structure and components of the DPOBE Model for Organizational Sustainability.

Being an investigation with several years of development around an initial theoretical model, only with a solid and validated structure, pillars and components, it was possible to transform it into a quantitative tool to measure the effective organizations sustainability in a way different from other existing sustainability tools and indexes.

\section{Acknowledgements}

The authors would like to thank all the colleagues who helped in making the inquiries and the facilities given by CICE-ESCE/IPS (Research Centre in Business Sciences), an investigation centre established in the School of Business Administration from the Polytechnic Institute of Setúbal (Portugal).

\section{References}

Almeida, F. (2007). Os desafios da sustentabilidade: uma ruptura urgente. Rio de Janeiro: Elsevier.

Anderson, R. (2006). The critical importance of sustainability risk management. Risk Management, 53 (4), 66-74.

Andrade, F. \& Anunciação, P. (2008). De la Calidad de los Portables Web a la Excelencia en los Servicios Publicos. In XIII Congreso Internacional del CLAD sobre la Reforma del Estado y de la Administración Pública - Buenos Aires. Conference proceedings.

Andrade, M. J. F. \& Anunciação, P. F. (2009). Customer Perception of Web Quality in Services. In $6^{\text {th }}$ International Conference on Management of Technological Changes - Alexandroupolis (Greece). Conference proceedings.

Anunciação, P. F. \& Zorrinho, C.D. (2006). Urbanismo Organizacional - Como Gerir o Choque Tecnológico nas Empresas. Lisboa: Edições Sílabo.

Atkinson, G. (2000). Measuring corporate sustainability. Journal of Environmental Planning and Management, 43 (2), 235-252.

Baumgartner, R. \& Ebner, D. (2010). Corporate sustainability strategies: sustainability profiles and maturity levels. Sustainable Development, 18 (2), 76. 
Bishop, T. (2006). Nonprofits, lawyers adopt 'focus group' research tool. Tribune Business News, $5^{\text {th }}$ February, 1. Boateng, W. (2012). Evaluating the efficacy of focus group discussion (FGD) in qualitative social research. International Journal of Business and Social Science, 3 (7), 54.

Chen, A. J., Boudreau, M. C. \& Watson, R. T. (2008). Information systems and ecological sustainability. Journal of Systems and Information Technology, 10 (3), 186-201.

Coral, E. (2002). Modelo de planeamento estratégico para a sustentabilidade empresarial. Brasil: Universidade Federal de Santa Catarina.

Danich, V.A. (2003). Uma contribuição à gestão empresarial socialmente responsável fundamentada no comportamento ético das organizações. Brasil: Universidade Federal de Santa Catarina.

Donaire, D. (2006). Gestão ambiental na empresa. São Paulo: Editora Atlas.

Dunphy, D. (2003). Corporate Sustainability: challenge to managerial orthodoxies. Journal of Australian and New Zealand Academy of Management, 9 (9), 2-11.

Dyllick, T. \& Hockerts, K. (2002). Beyond the business case for corporate sustainability. Business Strategy and the Environment, 11 (2), 130-141.

Duan, S. X. (2019). A Sustainability-Based Multi-Criteria Decision Approach for Information Systems Project Selection. Electronic Journal of Information Systems Evaluation, 22 (2), 67-77.

Ehrenfeld, J.R. (2005). The roots of sustainability. MIT Sloan Management Review, 46 (2), 22-25.

Elkington, J. (2001). Canibais com garfo e faca. São Paulo: Pearson Education do Brasil.

Epelbaum, M. (2004). Influência da gestão ambiental na competitividade e sucesso empresarial. Brasil: Universidade de São Paulo.

Gisbert López, M. C., Mendes, J. C., Anunciação, P. F., Andrade, F. J., Fernandes, C. R. \& Santos, J. R. (2011). 'Main challenges in organizational management for a sustainable development: a new perspective', in Papanikos, G.T., (ed.) International Developments in Management Research. Athens: Athens Institute for Education and Research, 63-82.

Gisbert López, M. C., Mendes, J. C., Anunciação, P. F., Andrade, F. J., Fernandes, C. R. \& Santos, J. R. (2010). Main challenges in organizational management for a sustainable development: a case study of the DPOBE Model for Organizational Sustainability. In GIRA 2010 - Corporate Governance, Innovation, Environmental \& Social Responsibility, Conference proceedings.

Grupe, F.H., Garcia-Jay, T. \& Kuechler, W. (2002). Is It Time For An IT Ethics Program?. Information Systems Management, 19 (3), 51-57.

Horak, S., Arya, B. \& Ismail, K. M. (2018). Organizational Sustainability Determinants in Different Cultural Settings: A Conceptual Framework. Business Strategy and the Environment, (27), 528-546.

Huemann, M. \& Silvius, G. (2017). Projects to create the future: managing projects meets sustainable development. International Journal of Project Management, 35 (6), 1066-1070.

Kim, W. C. \& Mauborgne, R. (2003). Fair Process: Managing in the Knowledge Economy. Harvard Business Review, 81 (1), 127-136.

Markides, C. (2000). All the Right Moves: A Guide to Crafting Breakthrough Strategy. Boston: Harvard Business School Press.

Moldavanova, A. \& Goerdel, H. T. (2018). Understanding the puzzle of organizational sustainability: toward a conceptual framework of organizational social connectedness and sustainability. Public Management Review, 20 (1), 55-81.

Markides, C. (1997). Strategic Innovation. Sloan Management Review, (38), 31-42.

Oliveira, P. H. D. (2007). Sustentabilidade empresarial: aplicação do modelo UNEP/UNESCO (1987) para avaliação do equilíbrio socioeconômico e ambiental das empresas. Brasília: Programa Multi-institucional das Universidades de Brasília, Federal da Paraíba, Federal de Pernambuco e Federal do Rio Grande do Norte.

Rajkumar, T. M. \& Mani, R. (2001). Offshore Software Development - The View From Indian Suppliers. Information Systems Management, 18 (2), 63-72.

Rodrigues, S. N. (2000). 'Comércio Electrónico e Valores Mobiliários' in Cadernos do Mercado de Valores 
Mobiliários. Lisboa: CMVM, (9), 80.

Santoro, R. C. (2003). Modelo para Implantação de Sistema de Indicadores Estratégicos, visando a Sustentabilidade Empresarial. Brasil: Escola Politécnica da Universidade de São Paulo.

Santos, J. R., Mendes, J. C. \& Anunciação, P. F. (2012). Sustainability Strength Index: an Improvement of the DPOBE Model for Organizational Sustainability. In TMS - Tourism and Management Studies International Conference-Algarve. Conference proceedings

Santos, J. C. R. (2012). Sustentabilidade Empresarial: o Estudo de Caso da MSF-Engenharia, S.A.. Faro: Faculdade de Economia da Universidade do Algarve.

Santos, J. R., ANUNCIAÇÃO, P. F. \& Svirina, A. (2013). A tool to measure organizational sustainability strength. Journal of Business Management, (7), 105-117.

Stacey, R. (1993). Organizações em Aprendizagem e Estratégias Emergentes, Pensamento Estratégico e Gestão da Mudança. Lisboa: Edições Dom Quixote.

Svirina, A. (2009). Measuring Managerial Efficiency: a Balanced Approach. In Global Conference on Business and Finance. Conference proceedings, 4 (1), 24-28.

Tworek, K., Walecka-Jankowska, K. \& Zgrzywa-Ziemak, A. (2019). The Role of Information Systems in Shaping Integrative Logic for Business Sustainability. Operations Research \& Decisions, 29 (4), 25-146.

United Nations (2019). The Paris Agreement [Accessed 20.03.2020]. Available from Internet: https://unfccc.int/process-and-meetings/the-paris-agreement/the-paris-agreement.

Wolfinbarger, M.F. \& Gilly, M.C. (2002). .comQ: Conceptualizing, Measuring and Predicting e-Tail Quality. Marketing Science Institute, Working Paper, Report \#02-100.

Worthen, B., Sonne, P. \& Scheck, J. (2012). Long Before the H-P Deal, Autonomy Had Red Flags. The Wall Street Journal, 28 November 2012, 14-15.

Yang, Z., Cai, S., Zhou, Z. \& Zhou, N. (2005). Development and validation of an instrument to measure user perceived service quality of inmodotion presenting Web portals. Inmodotion \& Management; (42), 575-589.

Yoo, B. \& Donthu, N. (2001). Developing a scale to measure the perceived quality of internet shopping sites (SITEQUAL). Quarterly Journal of Electronic Commerce, 2 (1), 31-47.

Zeithaml, V.A., Parasuraman, A. \& Malhotra, A. (2001). A conceptual framework for understanding e-service quality: implications for future research and managerial practice. MSI Working Paper Series, (115), 1-49.

Zeithaml, V.A., Parasuraman, A. \& Malhotra, A. (2002). Service Quality delivery trough Web sites: a critical review of extant knowledge. Journal of the Academic of Marketing Science, 30 (4), 362-375. 